\title{
VOLUNTARY OR COMPULSORY INTERVENTION IN FAMILY LIFE?
}

A care order, allowing the non-consensual removal of a child from parental care, has exacting requirements. A court must find that the child is suffering, or likely to suffer, significant harm caused by the absence of reasonable care or control (Children Act 1989, s. 31 - all other statutory references are to this Act). The child's welfare is paramount (s. 1), and the order must be human rights-compliant. Section 20, however, enables a local authority to accommodate a child without an order in certain circumstances, ostensibly with relevant parents' cooperation. While there is in principle a clear distinction between these voluntary and compulsory forms of intervention, contained in Parts III and IV (see also Part V) respectively, there is evidence of "misuse and abuse of section 20" (Re A (A Child), Darlington Borough Council v M [2015] EWFC 11, [100]), whereby councils accommodate children under it in arguably dubious circumstances while avoiding safeguards flowing from the timely seeking of a care order. In Williams v Hackney London Borough Council (Coram Children's Legal Centre and others intervening) [2018] UKSC 37, [2018] 3 W.L.R 503, the Supreme Court was more tolerant of local authorities' use of s. 20 than might have been expected, denying compensation to parents whose eight children had been accommodated under it.

When the claimants' 12-year-old son was caught shoplifting on 5 July 2007, investigating police judged the claimants' home unhygienic and dangerous for habitation and removed all of their children. They did so under s. 46, permitting the removal of a child to suitable accommodation (here provided by Hackney) for up to 72 hours on the basis of reasonable cause to believe he will suffer significant harm. The next day, having been bailed following their arrest, the claimants signed a "safeguarding agreement" at Hackney's offices, which provided inter alia "[t]hat all the children will remain in their foster placements for the present time". The parents signed agreements on accommodation and medical treatment on the same day. They were not informed of their rights to object to or remove the children from accommodation, and when they sought the children's return on 9 July (after the police protection period expired), they were told that they could not take their children home. On 13 July, the claimants' solicitors wrote two letters to Hackney, inter alia seeking information on "the current and future plans in this matter", stating that the parents were "very keen to have their children returned ... as soon as that is thought 
possible" and giving notice of an "intention to withdraw consent to the accommodation", albeit with a willingness to "work co-operatively with the local authority and ... agree to their continued accommodation for a further ten days" so that Hackney could make "any further investigations necessary". On 16 July Hackney decided that the children should be returned home as soon as possible. This was delayed until 11 September, however, because of the perceived need to remove bail conditions prohibiting the claimants from having unsupervised contact with their children.

In 2013, the parents sought damages. Dismissing other claims, Sir Robert Francis Q.C. held that the accommodation was not "in accordance with the law" under Article 8(2) ECHR after the police period expired, the claimants' consent not having been fully informed or fairly obtained, and awarded each parent $£ 10,000$ for breach of their ECHR rights ([2015] EWHC 2629 (QB)). Hackney successfully appealed ([2017] EWCA Civ 26) on the ground that there was a lawful basis for the relevant accommodation period because the bail conditions prevented the parents from providing suitable accommodation and meant that they were unable to do so, and also because there is no consent requirement in s. 20. The Supreme Court upheld that decision, on different grounds.

Giving the sole judgment, Lady Hale engaged in a thorough analysis of the previous case law, and helpfully but contestably formulated nine principles on s. 20 ([2018] UKSC 37 at [38]-[52]). Perhaps none are wholly new, but they perform a clarifying function and are likely to form the basis, and influence the balance, of future judicial approaches. First, in an important recognition of the dangers of s. 20, "no local authority have the right or the power to remove a child from a parent [with parental responsibility ("PR")] who is looking after the child and wants to go on doing so without a court order", even if the police do. Further, "[h]elpless submission to asserted power does not amount to a delegation of [PR] or its exercise". Secondly, it "may be confusing" to talk of "consent" (chiming somewhat with the Court of Appeal's rejection of a "consent" requirement), when what is really happening is a "delegation" of PR. While any such delegation must be "real and voluntary" and no parent should be given the impression that she has no choice in the matter, it can be "real and voluntary" without being "fully informed", even if best practice would require parents to be informed of their s. 20(7)-(8) rights to object to, or remove from, accommodation. Admittedly, "consent" does not appear in the section, but this 
approach has the potential immediately to undermine the first principle. Thirdly, Lady Hale enunciated a distinction potentially open to abuse by asserting that removing a child from parental care is "very different" from "stepping into the breach when a parent is not looking after [him]", and active consent is not required in the latter case.

Lady Hale reverted to a more parent-oriented approach in the next three propositions. Fourthly, parents may ask a local authority to accommodate a child, giving rise to either a duty (s. 20(1)) or a power (s. 20(4)) to do so. This is another form of delegation, and the second principle above applies. Fifthly, s. 20(7), on the ability of a parent with PR who is able and willing to provide care to "object" to local authority accommodation, "says nothing about the suitability of the parent or of the accommodation which the parent wishes to arrange". A lack of suitability thought likely to cause significant harm should trigger a Part V application. Sixthly, a parent with PR may remove a child from s. 20 accommodation at any time without notice under s. 20(8), subject only to the carer's power to do what is reasonable to safeguard or promote the child's welfare under s. 3(5). So "if a parent [with PR] unequivocally requires the return of the child, the local authority have neither the power nor the duty to continue to accommodate [him]". This aspect of Lady Hale's judgment is an important recognition of the fundamental rights of parents to look after their children unless compulsory intervention has been authorised.

Seventhly, and uncontroversially, s. 20(7)-(8) rights are qualified by court orders determining where a child is to live (s. 20(9)-(10)). Eighthly, and equally straightforwardly, once an accommodated child reaches 16 , there is no parental right to object or remove if he is willing to be accommodated (s. 20(11)). In her ninth and final principle, however, Lady Hale deferred significantly to local authority discretion. She emphasised that s. 20 places no limit on the length of time for which a child may be accommodated. While she asserted that the local authority's duties towards looked-after children inter alia require that "[s]ection 20 must not be used in a coercive way", and that it may be unreasonable or a breach of Article 8 to accommodate a child for a long period without bringing care proceedings, the precise scope of these qualifications will be difficult to establish.

Applying these principles to Williams, Lady Hale held that, because of the initial police protection, the appropriate focus was not on whether there had been a valid "delegation" (under her second principle), but on subsections (7)-(8). While the bail conditions were not an insuperable barrier to return (contrary to the Court of 
Appeal's analysis), it was difficult to construe the events of 9 July "either as a clear objection to the children's accommodation under section 20(7) or as an unequivocal request for their immediate return under section 20(8)" ([58]). No damages would be payable because the judge regarded the proportionality test as satisfied in any event. Lady Hale apparently (and contestably) thought the "accordance with the law" requirement secondary even if probably met. The solicitors' letters did not meet the "unequivocal" test for immediate return (under the sixth principle above) either because they indicated that the parents were reluctantly prepared to delegate their PR until Hackney felt able to return the children, and "that delegation was never unequivocally withdrawn" ([59]). There was thus no Article 8 breach because the accommodation had a lawful basis, even if proportionality could have been further explored below.

While the Supreme Court expressed some admirable concern about the potential over-use of s. 20, it flitted between family-oriented and council-oriented interpretations and one is left with considerable sympathy for the claimants. If they had more forcefully (or "unequivocally") demanded the return of their children or signalled an unwillingness to cooperate with Hackney, they risked such conduct being used "against them" in subsequent care proceedings. Like social workers (see Bainham, [2011] C.L.J 312), then, there are also circumstances in which vulnerable and suggestible parents are "damned if they do and damned if they do not".

BRIAN SLOAN 